Entomology has acquired the important collection of British Coleoptera (beetles) formed by the late Dr. David Sharp, who died in 1922. The collection comprises nearly 114,000 specimens, most of which were collected by Dr. Sharp himself. Dr. Sharp's general collection of Coleoptera, consisting of at least 300,000 specimens from all parts of the world, was purchased by the Museum in 1905. More than 4000 additional foreign specimens have been received with the British collection. The Trustees have approved the purchase for the Department of Geology of a collection of Nothosaurs from the Alpine Trias of Besano. These small swimming reptiles were precursors of the better known Plesiosaurs. The specimens acquired appear to belong to two species of the genus Pachypleurosaurus. There has been placed on exhibition in the Department of Geology, near the entrance, the first of a contemplated series of scenes representing the fish-fauna of succeeding geological epochs. It shows reconstruction-models of fish-like animals and true fishes that lived just when the Silurian was passing into the Devonian period. They are the earliest ' back-boned' animals of which fossil remains have been found. The models are posed in an illuminated scene, the surface of the underwater scene being just below the eye of a spectator of average height; at the eye-level, the distant hills of the Old Red Sandstone period are seen.

\section{Minerals at the Natural History Museum}

IN 1930 the experiment was tried of issuing a free guide-leaflet to the exhibition collections in the Mineral Department of the Natural History Museum at South Kensington. The distribution of the leaflet is helped by some attractive exhibits of popular interest placed near the entrance to the gallery. By these means a considerably larger number of visitors have been induced to take an intelligent interest in the collections. The fact that 20,000 of these leaflets have been taken away by visitors, none being left as litter, proves that they have been appreciated. In the four-paged leaflet, attention is especially directed to the various uses of minerals by giving lists of gemstones, ores of the metals, other minerals of economic importance, building and road stones, ornamental stones, and radium-bearing minerals, with the number of the cases in which each may be seen. A third issue of 10,000 copies of the leaflet is now available.

\section{Fellowships for Medical Research}

THE Rockefeller Medical Fellowships and the Dorothy Temple Cross Research Fellowships in Tuberculosis for the academic year 1932-33 will shortly be awarded by the Medical Research Council, and applications for either should be lodged with the Council not later than June 1. The Rockefeller Fellowships are provided from a fund with which the Medical Research Council have been entrusted by the Rockefeller Foundation, and are awarded to graduates who have had some training in research work in the primary sciences of medicine, or in clinical medicine or surgery, and are likely to profit by a period of work at a university or other chosen centre in the United States before taking up positions for higher teaching or research in the British Isles. A fellowship held in America will have the value of not less than $£ 350$ a year. The Dorothy Temple Cross Research Fellowships give special opportunities for study and research to persons "intending to devote themselves to the advancement by teaching or research of curative or preventive treatment of tuberculosis in all or any of its forms ". Candidates must be British subjects and must possess suitable medical, veterinary, or scientific qualifications. The fellowships will preferably be awarded to candidates who wish to make their studies or inquiries outside Great Britain, and are of the value of not less than $£ 350$ a year. It may also be possible to award a senior fellowship of considerably greater value to a specially well qualified candidate wishing to undertake an intensive study of some particular problem of tuberculosis at a chosen centre of work in another country. Particulars of these fellowships are obtainable from the Secretary, Medical Research Council, 38 Old Queen Street, Westminster, S.W.1.

\section{International Congress for Anthropology and Ethnology}

THE proposal for the constitution of an international congress for anthropology and ethnology, which was put forward by the Royal Anthropological Institute, has elicited some interesting expressions of opinion from continental anthropologists. Two communications which have been received by the Council are published in Man for April. Dr. Fritz Krause, of Leipzig, president of the Gesellschaft für Völkerkunde, has been in communication with a number of ethnologists in Austria, Sweden, Holland, and Denmark, and has found that nearly all of them would prefer a congress covering ethnology only. Dr. Krause himself personally is in favour of a congress of 'ethnic sciences', of which the mainstay and principal field would be ethnology; but with 'adjacent sciences'ethnic psychology, sociology, etc.-taken into account and permanently recognised. Dr. Krause has offered to push his inquiries further, and this offer the Council of the Institute has cordially accepted. The second communication is from the Very Rev. P. W. Schmidt, who concurs in the view that the interests of ethnology will be best served by a separate congress. In fact, he and his colleagues in Vienna consider that there should be separate congresses for ethnology, anthropology, and prehistory. It is felt, however, that a great advantage would be obtained from a periodically recurring joint congress of all three branches of study. A rotation of four meetings at intervals of two years between each, of which the fourth in each series should be a joint meeting of the three studies, is suggested. This has the obvious disadvantage of an inordinately long interval between the independent meetings in each subject.

\section{Medieval Sussex}

IN attempting to reconstruct the past geography of England, one of the chief difficulties is to bridge the gap between the Domesday Survey of 1086 and the topographical county descriptions of the seventeenth and eighteenth centuries. In a paper in Geography for March, Mr. R. A. Pelharn has indicated 
some sources from which data can be obtained for these centuries, and has outlined the use to which they may be put in the county of Sussex. The distribution of various types of building-stone, when a stone was used outside its area of occurrence in the fabric of a church, throws light on means of transport, especially the navigability of rivers, since waterways were the only satisfactory means of moving heavy materials. Evidence of this source can be strengthened by sheriffs' administrative accounts. These do not give the precise route but the distance and the cost of transport. The sheriffs' accounts also give much evidence concerning the distribution of crops, timber, and wool production. Lastly, much valuable information can be obtained from taxation accounts, particularly the lay subsidy of 1327. This gives a guide to the location of the areas of greatest prosperity. Mr. Pelham has illustrated his paper with maps of various aspects of the fourteenth century geography of Sussex.

\section{Ice in Arctic Seas}

THE Danish Meteorological Institute has published its report on the ice in arctic seas in 1930 (Isforholdene $i$ de Arktiske Have). There appears to have been a repetition of the unusual conditions marked by the lack of ice in many seas in 1930. In Spitsbergen the fjord ice was late in forming and relatively thin, and so early as April the western part of the north coast had open water, and by June there was access to the north-east. During July and August the waters of the archipelago were almost free from ice. In the Barents Sea the edge of the ice was unusually far north throughout the summer, and in August a great deal of Franz Josef Land was accessible in open water, which is not usual. The Kara Sea had scattered ice in July but was almost entirely clear in August. So late as November there was little ice in the White Sea. In the east coast of Greenland conditions were less abnormal, but from August until November there was little or no ice off Angmagssalik. The coasts of Iceland were free from ice throughout the year, and south-west Greenland had less ice than usual. Hudson Strait was clear of ice about a month earlier than usual and, except for icebergs, was still free in October. From Siberian waters there were few reports. On the north coast of Alaska the ice lay closely packed throughout the summer. The report is illustrated with the usual charts for each of the spring and summer months.

\section{Abstracts of Meteorological Literature}

The Meteorological Magazine for March 1932 contains particulars of a collection of abstracts of meteorological literature which has been undertaken by the Meteorological Office, Air Ministry. The abstracts are being gathered from various sources, including authors' own summaries, translated into English where necessary, and a number of meteorologists have volunteered their assistance in summarising papers for which no abstracts are otherwise available. The collection already numbers about a thousand, covering a period of nearly ten years, and it is hoped to include every important paper published in future. The abstracts are being classified according to subject, the classification adopted being that of the International Catalogue of Scientific Literature, which is also employed in the Royal Meteorological Society's Bibliography; the new collection of abstracts will thus form a very useful complement to the latter. The abstracts will not be published, but will be kept in the Meteorological Office Library for reference.

\section{Bibliography of Seismology}

THE study of earthquakes and of the transmission of earthquake waves through the earth has lately made such rapid advances that any attempt to enumerate the memoirs published is welcome. We have received from the Dominion Observatory at Ottawa, which is now solely responsible for its publication, copies of recent issues of the Bibliography of Seismology, edited by Mr. E. A. Hodgson. The number for July-Sept. 1931 contains the titles, with occasional brief abstracts, of a hundred papers. Most countries in which earthquakes are studied are represented, though somewhat unequally, more than one-half of the papers being published in the United States and Great Britain and only two in Italy.

\section{British School of Archæology in Iraq}

IT is announced that the subscribers to the fund for establishing a British School of Archæology in Iraq in memory of the late Miss Gertrude Bell have appointed a council on which the Universities of Oxford, Cambridge, Edinburgh, Durham, and London are represented. In addition, there are representatives of the British Museum, the British Academy, the Royal Geographical Society, the Royal Asiatic Society, the Society of Antiquaries, and other learned societies. The following have been appointed as officers: Sir Percy Cox (president), Sir Edgar Bonham Carter (chairman of the executive committee), Mr. E. H. Keeling (hon. secretary), and BrigadierGeneral Sir Osborne Mance (hon. treasurer). The offices of the School for the present will be at 20 Wilton Street, London, S.W.

\section{Scenery Preservation in New Zealand}

THE preservation of natural scenery by the institu. tion of reserves is an active policy of the New Zealand Government. The report on scenery preservation of the year ending March 31, 1931, records additional re. serves during the year of 131,415 acres, making a total of well over half a million acres. Notable additions include Lake Okareka and surroundings, and some two hundred square miles embracing the Fox Glacier, and the Copland and Twain Rivers, and many prominent mountain peaks. Some of the smaller reserves have been set aside for historical and anthropological reasons, but most are scheduled in order to preserve scenery and natural vegetation.

\section{Announcements}

THE Kelvin Medal of the Institute of Civil Engineers for 1932 has been awarded to the Marchese Guglielmo Marconi, and the presentation will be made by Lord Rutherford at the Institute on Tuesday next, May 3, at 5 P.M.

A VARLEX centenary commemoration meeting will be held at the Institution of Electrical Engineers on 